\title{
The Science and Public Policy Interface: Subset of a Larger Problem
}

\author{
David E. Shulenburger
}

Provost and Executive Vice Chancellor, University of Kansas

$\mathrm{H}$ igher education in the United States, particularly public higher education, is under considerable stress, a stress that affects every decision chancellors, presidents and provosts make, from faculty salaries to student tuition charges and library acquisitions. The stress comes from many sources but I believe much of it derives from the decision made implicitly in the legislative halls of every state, the decision that higher education is primarily a private good, not a public one. Private goods benefit the individual who receives them, while public goods benefit society at large. At least since the passage of the Morrill Act in 1862, the notion that higher education serves public ends has been widely accepted. But during the last thirty years, legislative opinion, as evidenced by legislative appropriations, has changed. We now appear to believe that higher education has such a private goods nature that it should be paid for primarily by those who receive it, the students, and to a smaller degree, by the public, which apparently is deemed to be only a minor beneficiary. Whether this change in judgment is justified by the ratio of private/public benefits derived from public higher education is not the focus of this paper; the focus is on the impact this judgment has had on the academy.

There are many consequences for this relative withdrawal of public support for higher education. Since the cost of providing higher education has increased while the public support was drawn down, a mad dash for replacement funding has ensued. Students, private donors, corporate donors, research foundations, etc., have become the new financers of higher education. As additional monies have come from these sources, so have additional demands and influences. Many of these demands have come from the U.S. government in the form of restrictions on the foci of research, but the U.S. government is hardly the only donor making demands on the academy.

I will review the financial situation of public four-year universities relative to that of private four-year institutions and then examine how that financial situation permits various donors to involve themselves in higher education's mission. With full credit to the authors, I will use both the data and format used by Thomas Kane and Peter Orszag in "State Support for Higher Education, Medicaid and the Business Cycle." 1

\footnotetext{
${ }^{1}$ Peter Orszag of the Brookings Institution, and Thomas Kane, UCLA, http://www.brook.edu/views/ papers/orszag/20021011.htm
} 
State legislatures have not appropriated funds to higher education proportional to the growth in personal
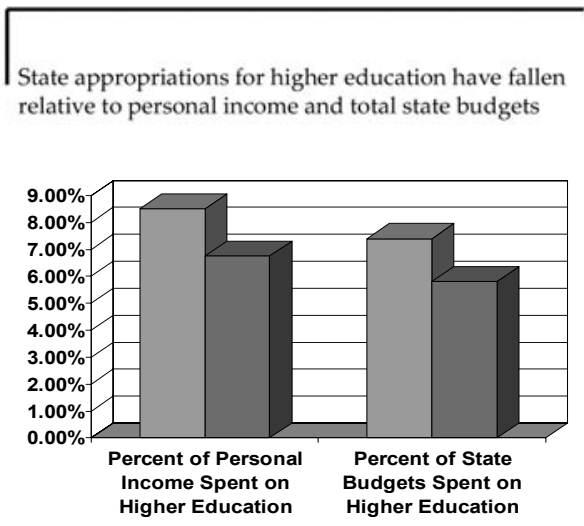

income. In 1977, 8.5\% of personal income was appropriated to support higher education. By 2003, this amount had fallen to under $7 \%$.

The decline in expenditure relative to total state expenditure shows the same trend. In 1977, just under $7.5 \%$ of state budgets went to higher education; in 2001 this percentage had fallen to about $5.75 \%$. In Kansas, as in the nation, higher education has been deemphasized as a recipient of state funding. The graph below shows the remarkable decline in the real state appropriation per student at The University of Kansas, Lawrence.

State General Fund Expenditures per Fall FTE Student University of Kansas - Lawrence (Amounts shown are in estimated FY 2005 inflation-adjusted dollars)

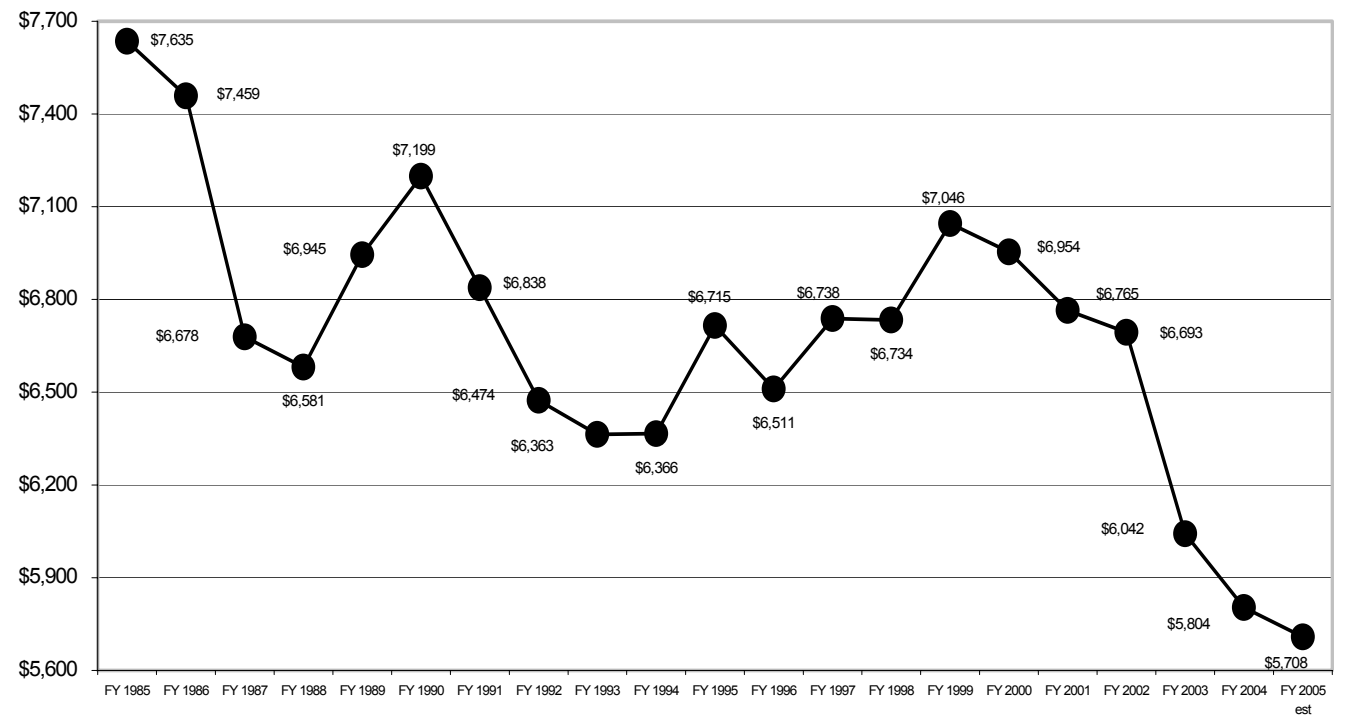

Public universities have responded by increasing tuition. Tuition as a proportion of funding grew from just over $13 \%$ of budgets in 1977 to over $18 \%$ in 1997. The state-funded portions of university budgets, my university included, comprise less than $25 \%$ of the total; universities like Colorado and
Virginia receive less than $10 \%$ of their total budgets from their states. In FY'05, for the first time at The University of Kansas, Lawrence, tuition revenue exceeded state general fund appropriations, which fell to approximately $22 \%$ of total university revenue. 


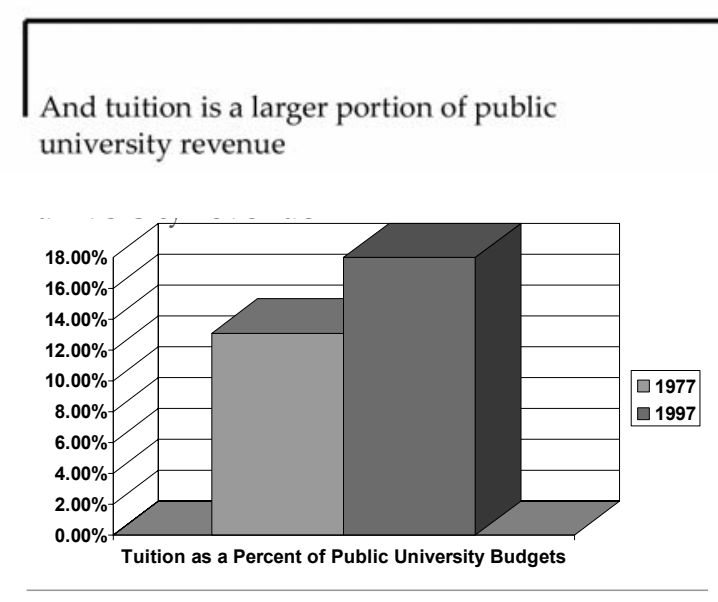

Private universities had no state support to lose. To compensate, they instituted tuition levels several times higher than their public counterparts and vigorously sought private endowments. Except for the occasional reversal in endowment levels caused by market fluctuations, this combination of endowment earnings and high tuition has given private universities a funding edge.

Spending per student at public institutions has not kept pace with that at private institutions

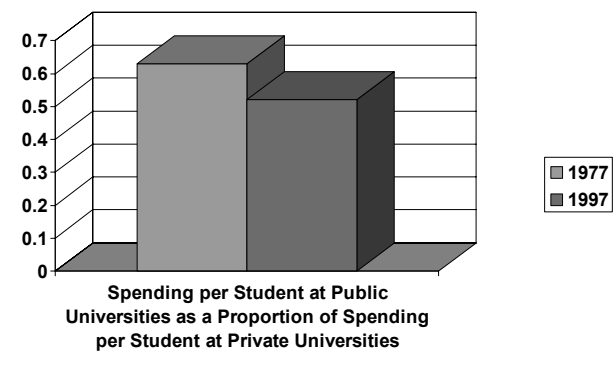

Kane and Orszag illustrate this advantage by examining the ratio of per student spending at private and public institutions. In 1977, public institutions spent $63 \%$ of what their private counterparts spent per student. By 1997 this amount had dropped to less than $55 \%$.

Salaries for professors at public research universities have declined relative to those at private

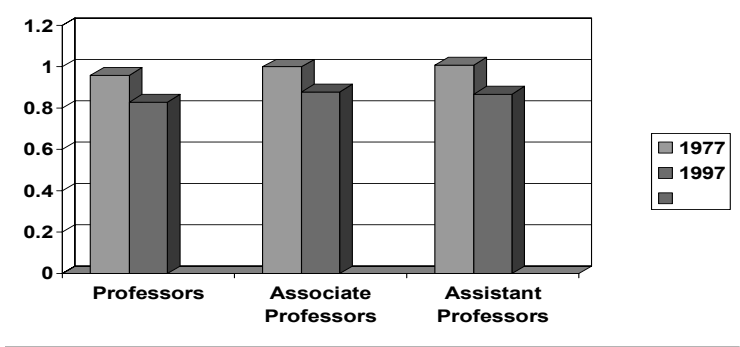

The biggest portion of any educational institution's budget is made up of faculty salaries. Given the lower level of tuition and relatively smaller state appropriation, it should not surprise you that salaries at public institutions have declined relative to salaries at private ones. In 1977, full professor salaries at public institutions were close to parity with those at privates; salaries of assistant professors were slightly greater, and associate professors were paid exactly on par. By 1997, the situation for all three categories had worsened considerably. At public institutions, professors' pay was at $82 \%$ of private

Student/Faculty ratios at public institutions increased while at private institutions they decreased

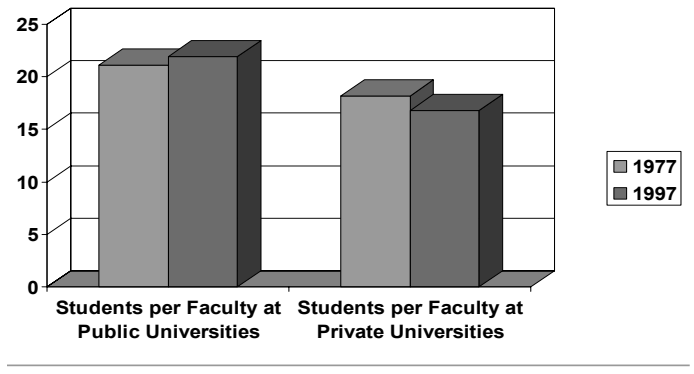


peers, associate professors were at $88 \%$, and assistant professors were at $84 \%$. Those differences are enough to cause those who are mobile to relocate and to lower morale for those who are not able to move.

Unfortunately, the reduction in relative salaries was accompanied by increases in teaching loads. In 1977, public universities had 21 to 1 ratios of students to faculty, compared to private universities with about 18 to 1 ratios. By 1997, the public institutions had risen to nearly 22 to 1 while ratios at private institutions had dropped to under 17 to 1 . A difference of three more students per faculty member in 1977 increased to five more students per faculty in 20 years, an increase large enough to be noticed by faculty and students alike.

Over 20 years this differentiation in resources was accompanied by increased differentiation in the quality of entering students at public and private universities. On both verbal and math SAT scores, the private institutions widened their advantage over their public brethren.

Tenured Faculty Perceptions:

"In recent years, has the quality of undergraduate education at your institution declined?"

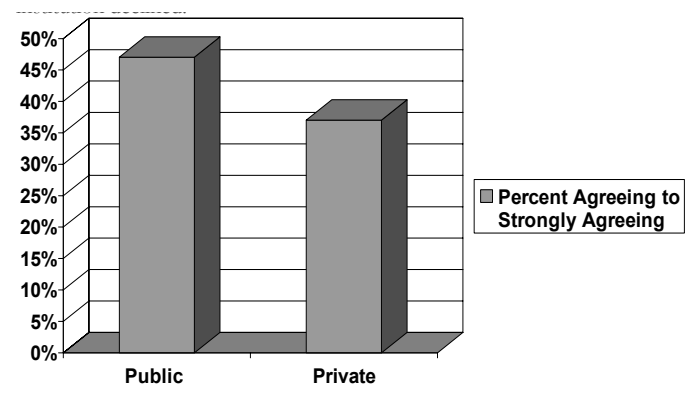

These student quality statistics are complemented by the perceptions of tenured faculty. Substantially more public than private faculty felt undergraduate education had declined in quality at their institutions.

The tuition increases that have been so much in the headlines are a defensive measure designed to keep the relative decline in the quality of public universities from growing worse. The stakes are high. As Kane and Orszag observe: "Since roughly three-quarters of college students are enrolled in public institutions implications could be substantial." "Substantial" indeed! The competitiveness of our country in science and industry may well rest in the balance.

When public institutions' historic patrons - state governments-withdraw support, those institutions either must choose to reduce their budgets or find other sources of funding. The former choice has severe, negative quality implications that are illustrated clearly by the previous data. The competition to public universities comes from private institutions. The decline in available funding per student already has had the apparent effect of relative quality reduction. In my judgment, the nation will be poorly served if we permit public 
higher education to fall further behind in quality relative to the private sector. My public university colleagues apparently share this view, as they are all vigorously seeking funding from many sources to replace rapidly decreasing state monies.

If the State is paying a smaller proportion who is paying a larger proportion?

Financial support from other
sources is increasing:
Tuition
Federal grants
Big-time athletics
Sale of intellectual property
Private giving
Exclusive commercial rights and
"sponsorships"

This search for additional funding has been successful to various degrees. Invariably, success causes public universities to confront a universal maximum: "He who pays the piper calls the tune." Donors, sponsors, vendors, and other funders generally want something for the money they contribute.

The Tune Called by Public Funders

- Stem cell research limitations

- Intelligent design

- Reproductive-related teaching and research

- Chimera

- Political pressure in the classroom-National Academy of Scholars

Universities increasingly have sought federal funding for research; this began with the passage of the Morrill Act, accelerated through the Sputnik era, and went into orbit with the recent doubling of NIH funding. This growing dependence on federal sources has permitted individuals and groups with agendas to constrain what might be done with federal research funding or to define narrowly the criteria that determine which scholars may receive funding. Clearly, scientists and university administrators believe that some of these limitations affect the quality of science and restrict research to less productive areas. Some of the items on the list represent current constraints while others are areas in which there is agitation to impose constraints. Those who propose such constraints clearly believe that their efforts are justified on ethical grounds. I do not attempt to contest motives. I do note that it is the need for federal funds that increasingly leaves universities open to pressure from politicians with agendas that have no basis in science.

The federal government proposes a subset of constraints in the name of national security. At first glance, these do not appear to be limits on university research, but rather actions to promote safety. Indeed, some do have an impact on national security but they also have the impact of reducing the availability or quality of the inputs to the research process or the competitiveness of the venues in which research findings can be distributed. The effect of these constraints imposed in the name of national security result in research universities being far less competitive for funding.

\section{National Security Tunes}

- Admission of international students

- Constraints on export of technology

- Constraints on publishing

- Constraints on research personnel who conduct sensitive research

- Questionable classification of research by government agencies 
Double-digit tuition increases have been the norm for public universities for the last several years. While the level of public tuition averages less than onethird that of private universities, the rate of increase, not the level, has captured the public's attention. Since public university tuition is established through a public process, students have political power. While this power may not have the effect of keeping tuition increases under double digits, it has had an impact on what the increased tuition "buys" for the students. The news is full of reports about luxury amenities popping up on university campuses around the nation, student and taxpayer outrage at the language proficiency of GTAs, and the steadily rising grades of college students. While no self-respecting university administrator would admit to "selling" such items in exchange for higher tuition, students seem to understand their newly acquired power to influence the "product" they receive.

Tuition Payer Tunes

- Recreation centers with big climbing walls

- Fewer international GTAs

- Grade inflation

- Liberal education vs careerism

- Apartment-like residence halls

Nearly all public research universities are engaged in big-time athletics. While few even pretend that athletics ticket revenues cover all expenses, all understand that reduced ticket sales or donations can make athletics more dependent on university funds. Many university administrators believe that athletic success opens political doors leading to increased general university funding and to donors who may support academic programs on top of their gifts to athletics. Some harbor the hope that athletic success will attract students and thereby provide needed tuition revenue. While there are empirical studies that cast doubt on the trickle down benefits that athletics provide to academic programs, big time athletic programs and supporters have access to those who make university decisions. Athletics thereby becomes another campus piper.

Athletic Tunes

- Luxury suites

- Strength centers

- Special admission consideration

Every university endowment fundraising effort begins with a strategic examination of where donor gifts can make a real difference in the quality of the institution. This examination establishes goals and targets for the campaign. In the postmortem of every campaign, the realization dawns that many specific goals and targets were not met and many non-strategic items were funded instead. Sometimes midcampaign corrections are necessary to mitigate the failure of initial strategic planning. Sometimes, however, gifts simply do not complement the strategic aims of the institution. Some such gifts end up being ultimately of greater value to the institution than the articulated priorities; many others do not. The various donor priorities may affect any of the categories that follow. 
Donor Tunes

- Facility priorities

- Faculty support priorities

- Student support priorities

- Program support priorities

Finally, the commercial world intrudes into the academy. While we pride ourselves on being temples that tower above such concerns, a reading of the Bible tells us that commercial intrusions into "sacred" institutions have a very long history. The current debate is whether these business-education agreements corrupt the soul of the academy or merely provide funds with which it can better carry out its mission.

\section{Commercial Tunes}

- Drink my soda

- Wear my shoes

Fortunately, academic administrators are adaptable. When many diverse donors wish to call many diverse tunes, the capable administrator perhaps can fit these requests into the institution's mission so that a potential cacophony becomes a symphony.

This feat is not magic. For example, donors often specify that scholarships go to individuals from specific geographic areas while the institution may wish to provide scholarships to the neediest or most capable students. The scholarship administrator proceeds according to institutional goals and identifies the neediest/best students. Probably one or more of the students in this group come from the scholarship donor's designated geographic area. Those students get the donor's scholarships and scholarship funds without such restrictions go to other students. The final array of recipients is consistent with the institution's priorities and the donor's wishes are satisfied.

In a more controversial area, the government now prohibits federal funding of stem cell research unless the cells are derived from certain specified lines. Universities seek federal funding to do permitted research and reallocate private funding or institutional funds to do research on other stem cell lines. The federal restriction is satisfied while the institution's mission to perform cutting edge research into all areas is satisfied.

How to cope with all this diverse music?

$$
\begin{aligned}
& \text { Create a harmony; e.g. } \\
& \text { - Use private funding to do } \\
& \text { stem cell research } \\
& \text { - Use unrestricted funds to } \\
& \text { compensate for restrictions } \\
& \text { - Use joint appointments with } \\
& \text { entities not constrained to } \\
& \text { avoid restrictions }
\end{aligned}
$$

Thus the clever university bureaucrat can dance to the donors' tunes without being unfaithful to the university's mission. Perhaps faculty and students view the resulting music as a masterpiece. But does this process have unwanted consequences?

Then, such restrictions do not matter?

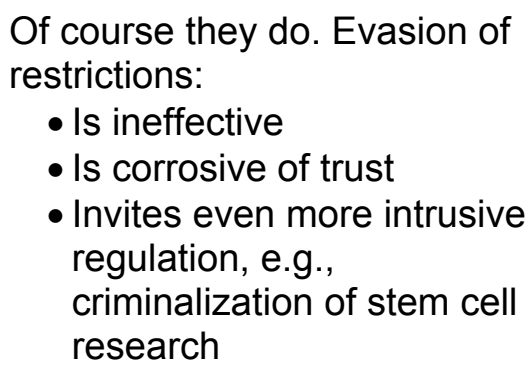

Yes, it does; harm is done. At a minimum, valuable administrative time is spent doing all the permutations 
needed to satisfy donor demands. Far less effort would be required to produce the same ends if unrestricted funds were available. More menacing is that this process of accommodation corrodes trust. The donor looks at the institution and sees that the clever tune he or she intended to call has not affected the overall behavior of the institution very much or at all. This revelation hardly encourages more giving. Rather it encourages the donor to tighten restrictions even more so that there is an impact on the institution. Imagine a scholarship donor who requires that ten percent of all scholarship recipients come from geographic area " $X$ " instead of requiring that his/her scholarship funds flow to recipients from "X." This restriction does impact the university's ability to carry out its mission.

Such donor restrictions can be eliminated by refusing to accept the funding if accepting causes more harm than doing without. Unfortunately, some donors have a coercive edge that arises from their legislative powers rather than from their purses. For example, Congress could prohibit by law all stem cell research. Such restrictions could not be evaded by clever bureaucrats and would cause real harm to science. Do attempts to circumvent restrictions simply enrage donors and cause them to seek more effective and destructive means to reach their ends? I fear so.

There is no substitute for understanding. Rather than using our brains to outwit those whose resources and power might enable them to restrict university activities, it would be far better if we could persuade them of the longterm good done by letting free inquiry characterize the academy. The larger society has been well served by academic freedom and this truth is evident all around us. We should not shy away from defending freedom of inquiry, but engage in the long, hard intellectual slog needed to defend it.

Long, hard slog to maintain or regain academic freedom
“. . . freedom to think as you will and to speak as you think are means indispensable to the discovery and spread of political truth." -Justice Louis D. Brandeis, Larkin vs. State of California, 1927

The challenges to preserve intellectual freedom from those who can use their influence to subvert the academy are enormous and may take years, perhaps decades, to show fruit. Unfortunately, the administrative leaders of the academy, presidents and provosts, tend to be in their positions for five years or fewer. This is hardly enough time to get the conversation going. Changing this equation by attracting good people into these positions and supporting them while they make the argument for the freedom of the academy is critical. Marshalling national education groups like the AAU, NASULGC, ACE and the AAUP to lead the fight on federal government issues can offset campus leadership's impermanence. The faculty, of course, go on forever and should not take lightly their responsibilities to speak out on issues that threaten to infringe campus prerogatives.

None of the above is intended to suggest that the academy should ignore society. We clearly must integrate the academic mission into society and be 
accountable to the broader community or risk losing the support necessary to succeed. On the other hand, the pressure to bend the long-term mission of the academy to the short-term desires of individuals is pernicious and will serve no one well in the long-term. Funding shortages recently have caused public universities to be particularly susceptible to such pressures. Let us work for understanding to redirect these pressures to the long term good of the academy and society. 